\title{
RESEARCH PAPER \\ ON-SITE EFFECTS AND COST OF FERTILITY EROSION FROM FIVE SMALL RESERVOIR CATCHMENTS IN THE UPPER EAST REGION OF GHANA
}

\author{
B. K. Amegashie ${ }^{1}$, C. Quansah ${ }^{1}$, A. W. Agyare ${ }^{2}$, M. Bonsu ${ }^{1}$ and S. N. Odai ${ }^{3}$ \\ ${ }^{1}$ Department of Crop Science, KNUST, Kumasi, Ghana \\ ${ }^{2}$ Department of Agricultural Engineering, KNUST, Kumasi, Ghana \\ ${ }^{3}$ Department of Civil Engineering, KNUST, Kumasi, Ghana
}

\begin{abstract}
A study was carried out in the Upper East Region of Ghana to assess the on-site effects and the cost of fertility erosion from five small reservoir catchments (Dua, Doba, Zebilla, Kumpalgogo and Bugri). The catchment soils and reservoir sediments were sampled and analyzed for their bulk density and nutrient content. The mean reduction in soil depth in the various catchments

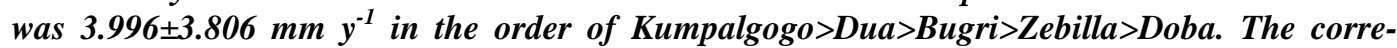
sponding decrease in the water holding capacity of the top $20 \mathrm{~cm}$ depth of the catchment soils ranged from 0.563 to $4.698 \%$ per year. The percentage loss in the total nutrient stocks in the top $20 \mathrm{~cm}$ of the catchments as eroded sediment-bound nutrients ranged from 9.63 to $64.71,7.87$ to 56.83, 6.12 to 54.82, 1.26 to 40.14, 49.86 to 12.65, 16.84 to 72.07 for $O C, N, P, K, C a$ and $M g$, respectively. The total amount of nutrient loss in $\mathrm{kg} \mathrm{ha}^{-1}$ among the reservoirs ranged from 2383 to 19672 for $O C, 153$ to 3048 for $N, 3.15$ to 42.59 for $P, 41$ to 290 for $K, 432$ to 2158 for Ca, and 63 to 483 for $M g$. The cost of $N, P$ and $K$ removed by erosion was calculated by the Replacement Cost Method. The total cost per year (GHc ha $\left.{ }^{-1} y^{-1}\right)$ of fertilizers (sulphate of ammonia, single superphosphate and muriate of potash) was 286.15 for Dua, 74.289 for Doba, 225.061 for Zebilla, 1119.997 for Kumpalgogo and 96.376 for Bugri. The study has amply shown that soil loss through erosion reduces top soil depth, nutrient stocks and the water holding capacity of catchment soils. This will adversely affect crop productivity if no control measures are implemented. This can also lead to land degradation.
\end{abstract}

Keywords: Deposited sediment, nutrient depletion, small reservoirs, fertility erosion, fertilizer

\section{INTRODUCTION}

Soil erosion is a major threat to continued and sustained agricultural production in Ghana particularly in the Sudan Savanna zone (Folly, 1997). The effect of erosion may be on-site and/or off-site. The latter consequences, shown by this study and detailed out by Adwubi et al. (2009), resulted from downstream siltation, which has reduced reservoir capacity, enhanced the risk of flooding and shortened the design life of the reservoirs studied.

The on-site damage, which affects the catchments where the erosion originates, includes soil structure degradation, increased erodibility, surface crusting and compaction. The loss of 
soil reduces depth, water and nutrient storage capacities of the soil (NSE-SPRPC, 1981). The reduction in moisture reduces the soil's potential to sustain plant growth, exposes the plants to frequent and severe water stress which ultimately results in reduced crop yields.

Whilst soil loss measurement is a characteristic of most erosion research in Ghana (Asiamah and Antwi, 1988), the above implications of erosion-induced loss in soil depth for on-site damage have received very little research attention. Yet such studies are very pertinent for designing sustainable land management strategies in areas such as the Sudan Savanna zone of Ghana.

In this zone, many of the soils have predominantly light-textured surface horizons and extensive areas of shallow concretionary and rocky soils with low water and nutrient holding capacities and limited capacity for agriculture (Quansah, 1990). The latter attributes are exacerbated by the on-going water erosion in the zone.

Soil loss and runoff are almost always accompanied by losses of plant nutrients. The process, termed fertility erosion (Ellison, 1950), is selective, in that finer particles relatively high in plant nutrients and organic matter are the most susceptible to erosion. Consequently the eroded sediments contain higher concentrations of organic matter and plant nutrients in available form than the in-situ soil (Quansah and BaffoeBonnie, 1981). Whilst it is useful to know the magnitude of soil nutrient losses to aid replenishment strategies, their on-site costs are equally important. Unfortunately, these aspects are scarcely studied because nutrient depletion is insidious (FAO, 1990; Gachene et al., 1997). In Ghana, Bøjö (1996) estimated the gross annual economic loss due to erosion which ranges from 2 to 5\% of the Agricultural Gross Domestic Product (AGDP). Using the replacement cost approach (RCA), Convery and Tutu (1990) assessed the cost of annual production loss through erosion and nutrient depletion in Ghana to be US\$161.4 million which was about $5 \%$ of the AGDP. Drechsel and Gyiele (1999) reported US\$ 115.4 million (about $4-5 \%$ of AGDP) as the cost of productivity loss in Ghana. Quansah et al. (2000) assessed the seasonal cost of $\mathrm{N}, \mathrm{P}$ and $\mathrm{K}$ lost through erosion under a maize monocrop grown under excessively tilled land (double ploughing +3 times harrowing +3 times spike tooth harrowing) to be US\$ 7.1 per hectare. In the context of the national economy, the World Bank et al. (2006) estimated the cost of land degradation (mainly soil erosion) to range from 1.1 to 2.4 percent of the GDP, corresponding to 2.9 to 6.3 percent of AGDP.

For countries such as Ghana whose economies depend heavily on the agricultural sector, the loss of agricultural productivity particularly through erosion, implies loss of revenue for the socio-economic development of the country (Bonsu and Quansah, 1992).

In order to contribute the requisite information for filling the above identified gaps in erosion research, this study aimed at assessing (i) the on-site effects of catchment erosion and (ii) the magnitude and cost of fertility erosion.

\section{MATERIALS AND METHODS \\ Study site}

The study was carried out on five representative small reservoirs in the Upper East Region of Ghana. Their characteristics are given in Table 1. The Upper East Region is the northeasternmost part of Ghana's 10 regions. It is located between latitudes $10^{\circ} 15^{\prime}$ and $11^{\circ} 10^{\prime}$ north and longitudes $0^{\circ}$ and $1^{\circ}$ west. It covers an area of $8,842 \mathrm{~km}^{2}$ with eight administrative districts (Bolga, Bongo, Builsa, KasenaNankana, Talensi Nabdam, Bawku West, Bawku East and Garu Tempani; Fig. 1). According to the 2000 population and housing census (GSS, 2005), the region has a population of 920,089 made up of 442,492 males and 477,597 females with a population growth rate of $3 \%$ per annum. The region has a high population density of 104.1 persons $\mathrm{km}^{-2}$ compared 
On-site effects and cost of fertility erosion...

80

to a national average of 79.3 persons $\mathrm{km}^{-2}$. Over $80 \%$ of the population live in the rural areas with agriculture as their major economic activity (Birner et al., 2005).

The climate is semi-arid with an aridity index of 0.54 and a unimodal rainfall pattern of about $1000 \mathrm{~mm}$ per annum lasting 5 to 6 months.
Rainfall is often erratic with considerable variations between successive rainy seasons, with regard to the time of onset, duration and amount of rainfall. Rainfall intensities are high, often exceeding soil infiltrability with a consequent generation of large volumes of runoff with high potential erosion rates (Liebe et al., 2005). Temperatures are consistently high, with

Table 1. Characteristics of studied reservoirs in Upper East Region of Ghana

\begin{tabular}{lllllllll}
\hline Reservoir & YR & A & SC & LS & DS & HD & SE & CE \\
\hline Doba & 1998 & 70 & 185 & 180.0 & 5 & 4.6 & 177 & 178 \\
Dua & 1997 & 35 & 99.6 & 98.6 & 1 & 4.2 & 228 & 229 \\
Zebilla & 1998 & 105 & 460.0 & 452.0 & 8 & 7 & 225.8 & 227.25 \\
Kumpalgogo & 1998 & 40 & 120.0 & N/A & N/A & 3.8 & 193 & 193 \\
Bugri & 1994 & 216 & 510.0 & 508.9 & 1.1 & 7.5 & 499.25 & 500.75 \\
\hline
\end{tabular}

$Y R$, year of rehabilitation; A, catchment area (ha); $S C$, design storage capacity $\left(10^{3} \mathrm{~m}^{3}\right)$;

$L S$, live storage $\left(10^{3} \mathrm{~m}^{3}\right) ; D S$, dead storage $\left(10^{3} \mathrm{~m}^{3}\right) ; \mathrm{HD}$, height of dam wall $(\mathrm{m})$;

$S E$, spillway elevation (m.s.l); CE, dam crest elevation ( $m$ )

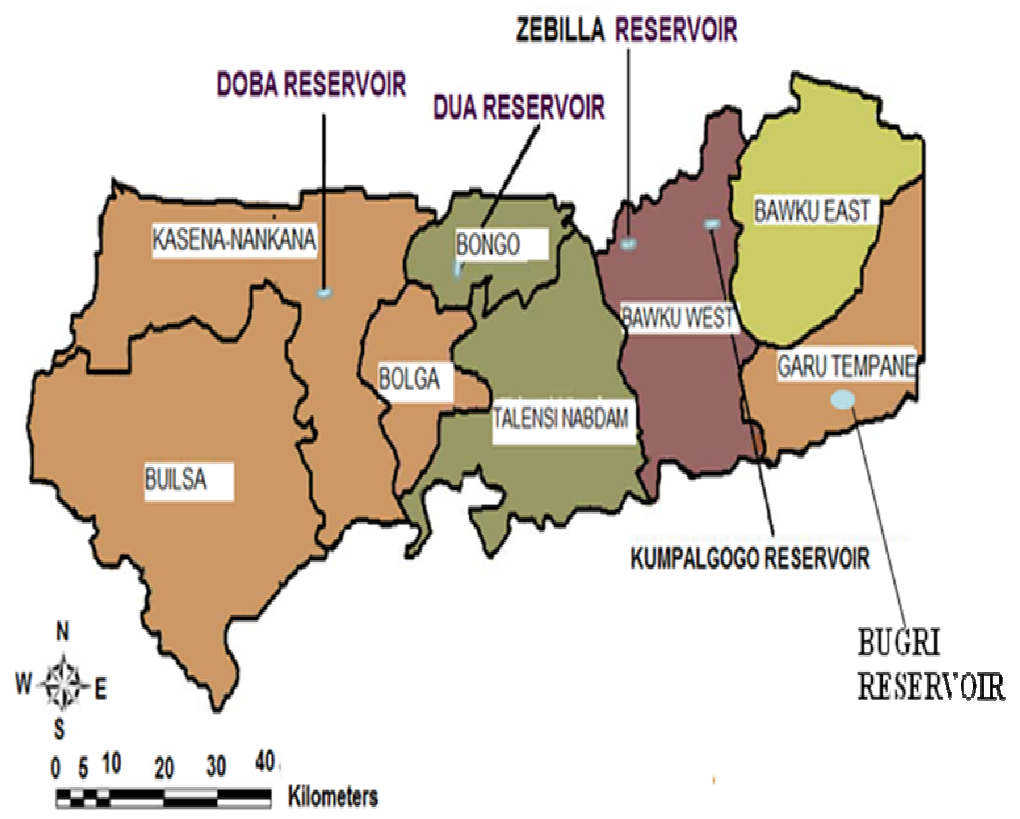

Fig.1: Location of study reservoirs and administrative districts in Upper East Region, Ghana 
an average of $28.6^{\circ} \mathrm{C}$. The mean annual relative humidity is $55 \%$. There is a high variability in temperature and relative humidity thereby resulting in high evapotranspiration levels (1652 $\mathrm{mm} / \mathrm{y}$ ) and drying of reservoirs.

The agroecology is Sudan savanna, consisting of short drought - and fire-resistant deciduous trees interspersed with open savanna grassland. Grass is very sparse with most areas exhibiting severely eroded soils. The soils in the area are generally developed from granites, Birimian rocks and alluvia of mixed origin (Asiamah, 1992). The major soils comprise Acrisols, Lixisols, Nitisols, Vertisols, Plinthosols, Cambisols, Gleysols (Asiamah, 1992; MoFA, 1998). A large part of the area $(82 \%)$ is underlain by metamorphic and igneous complexes with gneiss and granodiorite predominating (Fig. 2). Most of the soils are low in organic matter, buffering and cation exchange capacities and inherent fertility. The predominant clay mineral is kaolinite with nitrogen and phosphorus being mostly deficient.

\section{Site selection}

Due to time and limited financial resources, it was not possible to carry out this study on all reservoirs in the region. Five reservoirs representative of the catchments in the region were therefore selected for the study (Fig. 1).

This was done through desk study and reconnaissance survey with details presented by Adwubi et al. (2009).

\section{Catchment characteristics}

A large proportion of the catchments studied had gentle slopes less than 5 per cent. However in the upper slope reaches of the catchment, where homesteads and compound farms were located, the slopes could reach 10 per cent. All the reservoirs had patches of marshy land of varying sizes around them. These marshy sites served as sinks for sediment transported from the source areas thereby reducing the amount of sediment reaching the reservoirs. Some of the marshy sites were planted to rice. Land use in the catchments comprised compound farms cultivated to a variety of crops including millet (Panicum milliaceum), sorghum (Sorghum bicolor) and okra (Abelmoschus esculentus). The cultivation practices, including bullock ploughing, loosen the soil and make it more erodible. In some cases, vegetables are cultivated very close to the periphery of the reservoirs, as observed at Zebilla. Nutrient management mainly involved the use of farmyard manure and compost which are often inadequate. Mineral fertilizers are scarcely used. Crop production in the catchments therefore depended mainly on the low natural inherent fertility of the soils. Most of the reservoirs studied (Doba, Dua, Bugri and Kumpalgogo) had strips or patches of vetiver along their periphery, dam wall and spillway.

\section{Field Survey \\ Bathymetric survey}

Bathymetric survey is one of the methods used in quantifying sediment deposition in reservoirs that are filled with water and allow boat-based survey. Bathymetric surveys were conducted from $20^{\text {th }}$ September to $2^{\text {nd }}$ October 2007 to derive the current water storage capacity of the five reservoirs. The details of the reservoir sediment studies can be found in Adwubi et al., (2009).

\section{Reservoir sediment and catchment soil sam- pling \\ Reservoir sediments}

Undisturbed wet sediment samples of known volume were taken using a beeker sampler from each reservoir. The beeker sampler is a piston corer with clear perspex tubes $(\varnothing=57$ $\mathrm{mm})$ of different lengths (600, 1000 and 1500 $\mathrm{mm})$. At the bottom of the piston, an inflatable valve assures no sediment losses when raising the piston corer to the surface. Soil samples were taken from each reservoir $10 \mathrm{~m}$ away from the upstream end of the reservoir, 5-10 m away from the dam wall, in the middle of the reservoir and the remaining from other locations in the reservoir. In all, ten samples were collected from each reservoir with two samples per sampling point. One sample per sampling point was used for the determination of bulk 

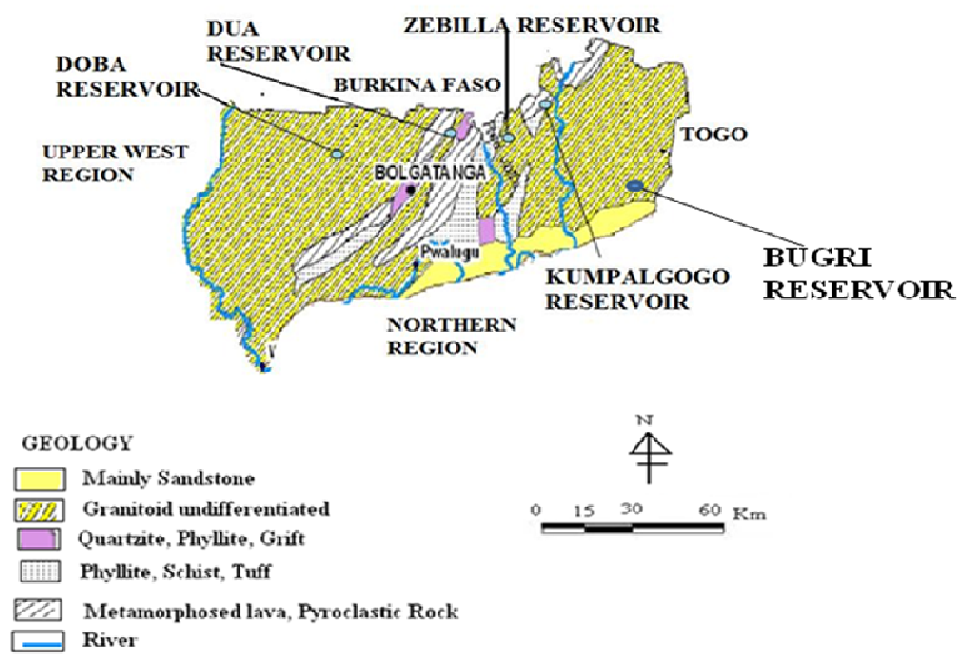

Fig. 2: Geology map of Upper East Region, Ghana, showing study sites (Kesse 1985)

density and the other for the particle size and soil chemical properties determination.

\section{Catchment soils}

In each catchment, soil samples were taken to a depth of $0-20 \mathrm{~cm}$ from the upper, middle and lower toposites along the soil catena. At each toposite, a composite sample made up of 10 bulked representative samples was taken for soil physical and chemical analyses.

\section{Chemical and physical analyses}

The following chemical and physical parameters were determined: $\mathrm{pH}$ using the Suntex $\mathrm{pH}$ (mv) Sp meter (701) for soil: water ratio of 1:2.5 (McLean, 1982), organic carbon (OC) by a modified Walkley-Black wet oxidation method (Nelson and Sommers, 1982), total N by Kjeldahl digestion and distillation procedure (Bremner and Mulvaney, 1982), available P by Bray $\mathrm{P}_{1}$ method (Olsen and Sommers, 1982), exchangeable bases $(\mathrm{Ca}, \mathrm{Mg}, \mathrm{K}$ and $\mathrm{Na}$ ) were determined in $1.0 \quad M$ ammonium acetate
$\left(\mathrm{NH}_{4} \mathrm{OAc}\right)$ extract (Black, 1965) and the exchangeable acidity $(\mathrm{H}$ and $\mathrm{Al})$ in $1.0 \mathrm{M} \mathrm{KCl}$ extract (McLean, 1965). Particle size distribution was by the hydrometer method (Bouyoucos, 1963) and bulk density of the catchment soils was by the metal core sampler method (Blake and Harte, 1986).

\section{Sediment volume determination}

The data collected from the bathymetric survey was analyzed using Golden Software Surfer 8 (Golden Software Inc., 2003). The elevation of the current reservoir bed (top of sediment) at each measurement point was defined by subtracting the recorded depth from the water surface level, measured with Automatic levelling instrument. Storage capacity and water surface area of the reservoirs at $1 \mathrm{~m}$ interval was calculated using Surfer's "Volume" function, based on which the current capacity curves of the reservoirs were constructed. The total volume of sediment deposition was then calculated by subtracting current water storage capacity from 
the initial water storage capacity.

\section{Sediment mass}

Sediment mass (SM) was calculated as:

$\mathrm{SM}=\mathrm{SV} \times \rho_{b}$

Where SV is sediment volume and $\rho_{b}$ is sediment bulk density

\section{Soil depth reduction due to soil loss}

The physical loss of soil through erosion reduces the depth of soil needed for water and nutrient storage and increased root room. It was expressed as:

$\rho_{\mathrm{b}}=\frac{M_{s}}{V_{t}}=\frac{M_{s}}{A x h}$

Where $\mathrm{h}$ is depth reduction due to soil loss (m), $M_{s}$ is weight of dry soil loss $(\mathrm{kg}), \mathrm{V}_{\mathrm{t}}$ is total volume of soil loss $\left(\mathrm{m}^{3}\right), \mathrm{A}$ is area from which soil is lost $\left(\mathrm{m}^{2}\right)$ and $\rho_{\mathrm{b}}$ is bulk density of in-situ soil from which eroded sediment originated $(\mathrm{kg}$ $\left.\mathrm{m}^{-3}\right)$.

\section{Reduction in water holding capacity due to loss in soil depth}

In this study, it is assumed that the water holding capacity of the surface $(20 \mathrm{~cm})$ sandy loam for Dua, loamy sand for Doba, Zebilla, Kumpalgogo, Bugri reservoirs, respectively, was $100 \mathrm{~mm}$ per metre soil depth (Hudson, 1995). Assuming even distribution of water along the metre depth, the top $20 \mathrm{~cm}$ depth will hold 20 $\mathrm{mm}$ of water (i.e. $0.1 \mathrm{~mm}) / \mathrm{mm}$ depth). Using the depth loss values (Equation 2) the percentage reduction in the water holding capacity of the top $20 \mathrm{~cm}$ was calculated as:

$\%$ Reduction in water holding capacity (WHC)

WHC $=\frac{(\text { depth } \operatorname{loss}(\mathrm{mm}) \times 0.1 \mathrm{~mm}) \times 100}{(20 \mathrm{~mm} \times 0.1 \mathrm{~mm})}$

\section{Total Nutrient Stocks}

The implication of nutrient loss for on-site productivity is the loss of the nutrient stocks in the catchment soils. Nutrient stocks of the top 20 $\mathrm{cm}$ depth of soil were calculated as the sum of remaining nutrients in the soil and that in the eroded sediments.

Total amount of nutrients and organic matter in the reservoir sediments

The total amount of nutrients and organic matter in the reservoir sediments were determined by multiplying the total weight of the reservoir sediments by the concentration of their nutrient constituents.

\section{Percentage $(\%)$ reduction in total nutrient stocks}

Percentage $(\%)$ reduction in the total nutrient stocks in the catchment soils was calculated as the ratio of the total of each nutrient in the eroded sediment and the total stock of each nutrient in the parent soil.

Estimation of Cost of Nutrients in the Eroded Sediments Using the Replacement Cost Method

The N, P and K content of the eroded sediments was converted to the forms in which they exist in straight fertilizers, i.e. $\mathrm{N}, \mathrm{P}_{2} \mathrm{O}_{5}$ and $\mathrm{K}_{2} \mathrm{O}(\mathrm{kg})$, respectively by multiplying by the following constants (Quansah et al., 2000)

$\operatorname{kg~N}=\operatorname{kg~N}$

$\mathrm{kg} \mathrm{P} \times 2.29=\mathrm{kg} \mathrm{P}_{2} \mathrm{O}_{5}$

$\operatorname{kg~K} \times 1.2=\mathrm{kg} \mathrm{K}_{2} \mathrm{O}$

The current cost of fertilizers per bag used in this study for estimating the cost of fertilizer lost was:

Sulphate of ammonia $(50 \mathrm{~kg})$ cost $=\mathrm{GH} \varnothing 30.00$

Single Superphosphate $(50 \mathrm{~kg})$ cost $=\mathrm{GH} \phi$ 45.00 and

Muriate of Potash $(50 \mathrm{~kg})$ cost $=\mathrm{GH} \notin 80.00$ 
Calculation of the number and cost of bags of fertilizer lost

Example: The Dua catchment

The losses of N, P and $\mathrm{K}$ from the catchment into the reservoir were:

Nitrogen $=536 \mathrm{~kg} \mathrm{~N} / \mathrm{ha}$

Phosphorus $=35.14 \mathrm{~kg} \mathrm{P} / \mathrm{ha}=80.47 \mathrm{~kg} \mathrm{P}_{2} \mathrm{O}_{5} / \mathrm{ha}$

Potassium $=290 \mathrm{~kg} \mathrm{~K} / \mathrm{ha}=348 \mathrm{~kg} \mathrm{~K} 2 \mathrm{O} / \mathrm{ha}$

$1 \mathrm{bag}$ of each straight fertilizer $=50 \mathrm{~kg}$

(i) $100 \mathrm{~kg}$ of Sulphate of Ammonia contains 21 $\mathrm{kg} \mathrm{N}$

Therefore $536 \mathrm{~kg} \mathrm{~N}=100 \mathrm{~kg} \times \frac{536 \mathrm{~kg}}{21 \mathrm{~kg}}=2552$

$.38 \mathrm{~kg} \div 50=51.05$ bags of Sulphate of Ammonia

(ii) $100 \mathrm{~kg}$ of Single Superphosphate contains 18 $\mathrm{kg} \mathrm{P}_{2} \mathrm{O}_{5}$

Therefore $80.47 \mathrm{~kg} \mathrm{P}_{2} \mathrm{O}_{5}=100 \mathrm{~kg} \times \frac{80.47 \mathrm{~kg}}{18 \mathrm{~kg}}$ $=447.06 \mathrm{~kg} \div 50=8.94$ bags of Single Superphosphate

(iii) $100 \mathrm{~kg}$ of Muriate of Potash contains $60 \mathrm{~kg}$ of $\mathrm{K}_{2} \mathrm{O}$

$348 \mathrm{~kg} \mathrm{~K} \mathrm{~K}_{2} \mathrm{O}=100 \mathrm{~kg} \times \frac{348 \mathrm{~kg}}{60 \mathrm{~kg}} \times 580 \div 50$

$=11.60$ bags of Muriate of Potash

The total cost of fertilizers lost was calculated by multiplying the number of bags of each straight fertilizer lost by the respective cost $/ 50 \mathrm{~kg}$ of each fertilizer.

\section{Statistical analysis}

The data obtained were analysed by Analysis of Variance (ANOVA) using GENSTAT Statistical Package (GENSTAT, 2007). Standard error difference (s.e.d) at 5\% was used to compare treatment means.

\section{RESULTS AND DISCUSSION}

On-site effects of catchment erosion

In order to assess the on-site effects of catchment erosion, soil-loss induced reduction in soil depth, water holding capacity and soil nutrient stocks in the various catchments were determined. The results are discussed in the following sections.

\section{Reduction in soil depth and water holding capacity}

The reduction in soil depth in the various catchments ranged from 0.1126 to $0.9396 \mathrm{~cm} \mathrm{y}^{-1}$.

(Table 2) The loss in soil depth does not only reduce rooting depth but the storage capacity of the soil for water and nutrients. The results of the study showed the reduction in the water holding capacity of the top $20 \mathrm{~cm}$ of the catchments to range from 5.44 to $42.28 \mathrm{~mm} \mathrm{y}^{-1}$ for Doba and Kumpalgogo, respectively (Table 2).

In a predominantly rainfed-agricultural zone, such as the study area, where shallow soils are common and smallholder farmers depend on the relatively nutrient rich $20 \mathrm{~cm}$ top soil with its in-situ moisture storage for growing their crops, the reduced soil depth and water holding capacity will have significant adverse impacts on crop growth, yield and agricultural productivity. Thames and Cassel (1979) demonstrated a close relationship between soil depth, available water capacity and dry matter production on a sandy soil with a shallow fragipan horizon. For soil depths of 26, 29 and $45 \mathrm{~cm}$, the respective available water capacities $(\mathrm{mm})$ were 32 , 52, 64 and dry matter $\left(\mathrm{t} \mathrm{ha}^{-1}\right)$ was 5.9, 7.4 and 9.1 .

According to Lal (1984) the majority of tropical soils have edaphically inferior subsoil and shallow rooting depth as observed in most soils in the Sudan savanna zone underlain by petroplinthite. Consequently, crop yield declines drastically as topsoil thickness is reduced. A major concern is that, the loss of the surface layer cannot be fully compensated for by additional inputs of nutrients as demonstrated by Mbagwu et al. (1983). Research information on the ef- 
Table 2. Loss of depth and reduction in water holding capacity (WHC) due to cumulative soil loss

\begin{tabular}{|c|c|c|c|c|c|c|}
\hline Reservoir & Age & $\begin{array}{c}\text { Bulk Den- } \\
\text { sity } \\
\left(\mathrm{kg} \mathrm{m}^{-3}\right)\end{array}$ & $\begin{array}{c}\text { Sediment } \\
\text { Mass (t) }\end{array}$ & $\begin{array}{c}\text { Depth } \\
\text { Loss } \\
(\mathrm{mm}) \\
\end{array}$ & $\begin{array}{l}\text { Depth loss } \\
\text { per year } \\
\left(\mathrm{mm} \mathrm{y}^{-1}\right)\end{array}$ & $\begin{array}{c}\text { Reduction in WHC } \\
\text { per year } \\
\left(\mathrm{mm} \mathrm{y}^{-1}\right)\end{array}$ \\
\hline Dua & 10 & 1511.96 & 35,183 & 66.49 & 6.649 & 33.25 \\
\hline Doba & 9 & 1508.10 & 11,480 & 10.87 & 1.208 & 5.44 \\
\hline Zebilla & 9 & 1640.31 & 24,849 & 14.43 & 1.603 & 7.22 \\
\hline Kumpalgogo & 9 & 1638.35 & 55,413 & 84.56 & 9.396 & 42.28 \\
\hline Bugri & 13 & 1589.93 & 50,310 & 14.64 & 1.126 & 7.32 \\
\hline Average & & 1577.73 & 3516.37 & 38.20 & 3.996 & 19.10 \\
\hline
\end{tabular}

fect of soil depth reduction due to natural erosion is scanty. Most of the evidence is from artificially desurfaced experiments. Lal (1976) reported a maize yield reduction of $23 \%$ after removing $2.5 \mathrm{~cm}$ of topsoil of an Alfisol in Ibadan, Nigeria. In Cameroon the removal of $2.5 \mathrm{~cm}$ topsoil caused a $50 \%$ drop in maize yield (Rehm, 1978).

A major factor of significance in the loss of soil depth due to erosion is the length of time it takes to replace the lost soil. Hudson (1995) estimated that, under ideal soil conditions in the tropics the rate of new soil formation was about $2.5 \mathrm{~cm}$ in 30 years (i.e. $0.83 \mathrm{~mm} / \mathrm{y}$ ). From other sources (Lal, 1987), new soil is formed at the rate of about $2.5 \mathrm{~cm}$ in 300 to 1000 years (i.e. 0.083 to $0.025 \mathrm{~mm} \mathrm{y}^{-1}$ ) under normal conditions. Available information suggests that it takes hardly one year to lose $1 \mathrm{~cm}$ of topsoil but 1000 years to replace it (Lal, 1984). In this study it has taken 9 to 13 years to lose 1.1 to $8.4 \mathrm{~cm}$ of topsoil which, by the above calculations by Lal (1984), will take between 1000 to 8000 years to replace. The mismanagement of the reservoir catchments can therefore readily lead to irreversible soil degradation.

\section{Reduction in soil nutrient stocks}

Apart from the physical loss of soil depth and water holding capacity, the soil lost through erosion is usually the most fertile part containing the plant nutrients, humus and any fertilizers that the farmer has applied. The implication of nutrient loss for on-site soil fertility and productivity is the loss of the nutrient stocks in the catchment soils. In order to assess this loss, the nutrient stocks of the top $20 \mathrm{~cm}$ depth of each catchment were calculated. The results (Table 3 ) showed the total nutrient stocks $\left(\mathrm{kg} \mathrm{ha}^{-1}\right)$ in the top $20 \mathrm{~cm}$ to range from 19084 to 30399 , 1884 to $5363,39.79$ to $80.34,147$ to 3253 , 2040 to 4328,358 to 784 for OC, N, P, K, Ca and $\mathrm{Mg}$, respectively. For a period of 9 to 13 years, representing the ages of the reservoirs, the percentage loss in the total nutrient stocks in the catchments (Table 4) as eroded sedimentbound nutrients ranged from 9.63 to $64.71,7.87$ to $56.83,6.12$ to $54.82,1.26$ to $40.14,49.86$ to $12.65,16.84$ to 72.07 for OC, N, P, K, Ca and $\mathrm{Mg}$, respectively.

These losses are indicative of the magnitude of soil productivity loss in the catchments. Crops grown on such soils will, implicitly, produce low yields with potential adverse effects on 
On-site effects and cost of fertility erosion. 86

Table 3. Total nutrient stock in the catchment soils

\begin{tabular}{lcccccc}
\hline Reservoir & OC & N & P & K & Ca & Mg \\
& & \multicolumn{2}{c}{$\mathbf{k g} / \mathbf{h a}$} & & & \\
\hline Dua & 19084 & 2154 & 80.34 & 806 & 4328 & 776 \\
Doba & 24733 & 1945 & 39.79 & 968 & 2040 & 358 \\
Zebilla & 23656 & 1884 & 60.35 & 147 & 2561 & 483 \\
Kumpalgogo & 30399 & 5363 & 77.69 & 1707 & 3387 & 784 \\
Bugri & 21916 & 2371 & 51.45 & 3253 & 2991 & 374 \\
Average & $\mathbf{2 3 9 5 7 . 6}$ & $\mathbf{2 7 4 3 . 4}$ & $\mathbf{6 1 . 9 2}$ & $\mathbf{1 3 7 6 . 2}$ & $\mathbf{3 0 6 1 . 4}$ & $\mathbf{5 5 5}$ \\
\hline
\end{tabular}

Table 4. Percentage reduction of total nutrient stock in the catchment soils

\begin{tabular}{lcccccc}
\hline Reservoir & OC & N & P & K & Ca & Mg \\
\hline Dua & 31.25 & 24.88 & 43.74 & 35.98 & 49.86 & 62.24 \\
Doba & 9.63 & 7.87 & 10.03 & 5.99 & 12.65 & 72.07 \\
Zebilla & 13.94 & 32.64 & 11.52 & 40.14 & 38.58 & 38.10 \\
Kumpalgogo & 64.71 & 56.83 & 54.82 & 16.17 & 44.73 & 55.10 \\
Bugri & 16.75 & 16.03 & 6.12 & 1.26 & 14.44 & 16.84 \\
Average & $\mathbf{2 7 . 2 6}$ & $\mathbf{2 7 . 6 5}$ & $\mathbf{2 5 . 2 5}$ & 19.91 & $\mathbf{3 2 . 0 5}$ & $\mathbf{4 8 . 8 7}$ \\
\hline
\end{tabular}

household food availability and security. In such a situation, more fertilizer amendments are needed to maintain crop yield. This increases production cost which many smallholder farmers cannot afford. Farmers are therefore compelled to grow their crops with little or no soil amendments leading to soil nutrient mining; yet the addition of mineral fertilizers alone cannot compensate for the productivity loss.

The loss of agricultural production in the affected districts and communities, as shown by crop production figures of the Upper East Region of Ghana (MoFA, 2009), means a loss of household incomes, agricultural revenue and delayed district plans for development. The rural population finds life increasingly hard and seeks a better life in the towns and cities. In the study area, this is exemplified by the seasonal migration of the youth to the south of the country during the long dry season to search for jobs and better living standards. These impacts underscore the urgent need to promote sustainable land management interventions in the catchments of reservoirs and other water bodies in the Sudan savanna zone as enshrined in Ghana's Agricultural Sustainable Land Management Strategy and Action Plan (2009-2015) (MoFA, 2008). In these developments, it is recommended that the watershed is taken as the planning unit and integrated watershed management effected by involving the active participation of the affected communities. 
Total amounts of nutrients and organic matter in the reservoir sediments

An examination of nutrient concentrations in soils and reservoir sediments showed the latter to contain higher concentrations of organic matter and plant nutrients in available form than the original soil. The assessment of the total amount of soil fertility constituents lost from the catchments was therefore necessary to ascertain the magnitude of soil fertility decline. The results are presented in Table 5.

The total carbon content of the reservoir sediments varied between 2383 and $19672 \mathrm{~kg} \mathrm{ha}^{-1}$ with a mean value of $6997.6 \mathrm{~kg} \mathrm{ha}^{-1}$. There was a considerable spatial variability in the organic carbon among the reservoirs as indicated by the $\mathrm{CV}$ of 40.8 per cent. Kumpalgogo recorded significantly greater organic carbon storage than the remaining reservoirs which had no significant differences in their OC contents.

Organic matter is one of the first soil constituents to be removed through erosion, yet it is among the hardest to replace. It is the main source of nitrogen, phosphorus and sulphur for crops in no-fertilizer smallholder agriculture (Acquaye, 1990). It is estimated that in tropical soils, the humus content accounts for 80 per cent of the cation exchange capacity under savanna conditions. Therefore the loss of soil organic matter does not only result in the depletion of one of its valuable components, but significant quantities of nutrients, such as nitrogen and phosphorus are removed with organic matter.

The high losses of organic matter are of particular concern because mineral fertilizers are far less effective in supplying nutrients on soils which are low in organic matter than those which contain adequate amounts of it (Swift, 1997). The implication is that if the losses of N, $\mathrm{P}$ and $\mathrm{K}$ from the catchments were to be replenished by mineral fertilizers, the desired effect on crop yield would hardly be attained because of the low soil organic matter. Soil fertility replenishment in the catchments should therefore aim at integrated nutrient management. This should involve the combined use of organic and inorganic inputs for sustaining soil fertility and crop yield (Swift, 1997; Sanchez et al., 1997; Quansah, 1997).

The losses of nitrogen varied from $153 \mathrm{~kg} \mathrm{ha}^{-1}$ to $3048 \mathrm{~kg} \mathrm{ha}^{-1}$ for Doba and Kumpalgogo reservoirs respectively with a mean of $946.4 \mathrm{~kg}$ ha

${ }^{-1}$. Except for Doba and Bugri, Bugri and Dua

Table 5. Total amount of nutrients in eroded sediment for five (5) reservoirs in the Upper East Region of Ghana

\begin{tabular}{lllllll}
\hline Reservoirs & OC & N & $\begin{array}{l}\text { P } \\
\text { kg/ha }\end{array}$ & K & Ca & Mg \\
\hline Dua & 5964 & 536 & 35.14 & 290 & 2158 & 483 \\
Doba & 2383 & 153 & 3.99 & 58 & 258 & 113 \\
Zebilla & 3297 & 615 & 6.95 & 59 & 988 & 184 \\
Kumpalgogo & 19672 & 3048 & 42.59 & 276 & 1515 & 432 \\
Bugri & 3672 & 380 & 3.15 & 41 & 432 & 63 \\
Average & $\mathbf{6 9 9 7 . 6}$ & $\mathbf{9 4 6 . 4}$ & $\mathbf{1 8 . 3 6}$ & $\mathbf{1 4 4 . 8}$ & $\mathbf{1 0 7 0 . 2}$ & $\mathbf{2 5 5}$ \\
s.e.d & 2333.6 & 213.3 & 2.964 & 36.6 & 155.2 & 84.3 \\
CV $(\%)$ & 40.8 & 27.6 & 19.8 & 30.9 & 17.8 & 40.5 \\
\hline
\end{tabular}


On-site effects and cost of fertility erosion...

and Dua and Zebilla, all other differences in total nitrogen were significant. The variability in the total $\mathrm{N}$ content of the reservoirs was medium according to Warrick's (1998) guidelines for variability of soil properties.

The total available phosphorus in the reservoir sediments ranged from 3.15 to $42.59 \mathrm{~kg} \mathrm{ha}^{-1}$ with a mean of $18.36 \mathrm{~kg} \mathrm{ha}^{-1}$. The differences in the available $\mathrm{P}$ content among the reservoirs were significant. The magnitude of $\mathrm{P}$ content was smaller than all the other nutrients probably due to its low mobility.

Nitrogen and phosphorus losses also present a major concern considering that they are the most deficient nutrients in savanna soils. On the other hand, soluble forms of nitrogen (nitrate and ammonium) constitute a major source of pollutants in rivers, lakes, reservoirs and groundwaters.

Total potassium losses showed medium variation $(\mathrm{CV}=31 \%)$, according to Warrick's (1998) guidelines for variability of soil properties, among the reservoirs and ranged between 41 and $290 \mathrm{~kg} \mathrm{ha}^{-1}$ with a mean of $144.8 \mathrm{~kg} \mathrm{ha}^{-1}$. The Dua and Kumpalgogo reservoirs recorded significantly greater $\mathrm{K}$ content in their sediments than the three other reservoirs which did not differ significantly in their K content.

The results showed that the catchments have lost tremendous amounts of $\mathrm{Ca}$ in the range of
432 to $2158 \mathrm{~kg} \mathrm{ha}^{-1}$ with a mean of $1070.2 \mathrm{kgha}$ ${ }^{-1}$. The Dua reservoir recorded the highest $\mathrm{Ca}$ content, followed by Kumpalgogo, Zebilla, Bugri and Doba. The differences in the Ca content were significant.

The total magnesium losses varied from $63 \mathrm{~kg}$ $\mathrm{ha}^{-1}$ to $483 \mathrm{~kg} \mathrm{ha}^{-1}$ with a mean of $255 \mathrm{~kg} \mathrm{ha}^{-1}$. The Dua and Kumpalgogo reservoirs had significantly higher values than the remaining reservoirs. The variability in $\mathrm{Mg}$ content among the reservoirs was rated medium $(\mathrm{CV}=40.5 \%)$. The contribution of the other nutrients, such as potassium, magnesium and calcium in sustaining crop growth and yield is no less important. The huge amounts of nutrient losses from the catchments, stored in the reservoir sediments, have cost implications for nutrient replenishment in the catchments for sustainable agricultural production.

The significant amount of nutrients and organic matter in the reservoir sediments as shown by the loss in soil nutrient stocks, is indicative of the magnitude of soil fertility and productivity decline in the contributing catchments as well as pollution of the reservoir waters.

The practice of integrated soil, water and nutrient management and conservation would be required to sustain the fertility and productivity of the catchments and avert the pollution of the reservoirs by nutrients and sediments exported from the catchments through erosion.

Table 6. Equivalent forms in fertilizers of total nutrients in deposited sediments

\begin{tabular}{|c|c|c|c|}
\hline \multirow[t]{2}{*}{ Reservoir } & \multirow[t]{2}{*}{ Total N } & $\mathrm{P}_{2} \mathrm{O}_{5}$ & $\mathrm{~K}_{2} \mathrm{O}$ \\
\hline & & \multicolumn{2}{|c|}{ kg/ha } \\
\hline Dua & 536 & 80.47 & 348 \\
\hline Doba & 153 & 9.14 & 69.60 \\
\hline Zebilla & 615 & 15.92 & 70.80 \\
\hline Kumpalgogo & 3048 & 97.53 & 331.20 \\
\hline Bugri & 380 & 7.21 & 49.20 \\
\hline
\end{tabular}




\section{Estimating Cost of Nutrients in the Eroded Sediments}

In estimating the cost of fertility erosion, the eroded sediment-bound nutrients were converted to existing fertilizers in the form of sulphate of ammonia, single superphosphate and muriate of potash. The results showed the nutrient losses to range from 153 to $3048,7.21$ to 97.53 and 49.20 to 331.20 for nitrogen, phosphorus $\left(\mathrm{P}_{2} \mathrm{O}_{5}\right)$ and potassium $\left(\mathrm{K}_{2} \mathrm{O}\right)$, respectively (Tables 6). The conversion of the nutrient loss to bags of fertilizer per hectare gave values in the range of 14.57 to $290.29,0.80$ to 10.84 and 1.64 to $11.60 \mathrm{bags}$ per hectare for sulphate of ammonia, single superphosphate and muriate of potash respectively (Table 7).

On the other hand, the cost of fertilizers lost ranged from 437.10 to $8708.70,36.00$ to 487.80 and 131.20 to $928.00 \mathrm{GH} \notin /$ hectare for sulphate of ammonia, single superphosphate and muriate of potash respectively (Table 8). The total cost $\left(\mathrm{GH} \varnothing \mathrm{ha}^{-1} \mathrm{y}^{-1}\right)$ of these fertilizers was 286.15 for Dua, 74.289 for Doba, 225.061 for Zebilla, 1119.997 for Kumpalgogo and 96.376 for Bugri. The values represent a hidden cost to agricultural production in the respective reservoir catchment areas. This implies that if straight fertilizers were to be bought to compensate for the losses of $\mathrm{N}, \mathrm{P}$ and $\mathrm{K}$ from the respective catchment areas of the reservoirs, the above costs will be incurred.

These cost figures, at best, represent only the cost of the mineral fertilizers required to replace the lost N, P and K and do not account for the losses of other nutrient elements including micronutrients nor the cost of transporting the fertilizers to the catchment areas as well as their application. Therefore the interpretation of the results of the replacement cost approach for assessing the cost of erosion as it affects prod-

Table 6. Equivalent forms in fertilizers of total nutrients in deposited sediments

\begin{tabular}{lccc}
\hline Reservoir & Total $\mathbf{N}$ & $\mathbf{P}_{\mathbf{2}} \mathbf{O}_{\mathbf{5}}$ & $\mathbf{k} / \mathbf{h a}$ \\
\hline Dua & 536 & 80.47 & 348 \\
Doba & 153 & 9.14 & 69.60 \\
Zebilla & 615 & 15.92 & 70.80 \\
Kumpalgogo & 3048 & 97.53 & 331.20 \\
Bugri & 380 & 7.21 & 49.20 \\
\hline
\end{tabular}

Table 7. Bags of fertilizer lost per hectare per year

\begin{tabular}{lccc}
\hline Reservoir & Sulphate of ammonia & $\begin{array}{c}\text { Single superphosphate } \\
\text { Bags/ha/y }\end{array}$ & $\begin{array}{c}\text { Muriate of potash } \\
\text { Dua }\end{array}$ \\
Doba & 5.104 & 0.894 & 1.160 \\
Zebilla & 1.619 & 0.113 & 0.258 \\
\hline
\end{tabular}


Table 8. Cost of fertilizers lost per hectare

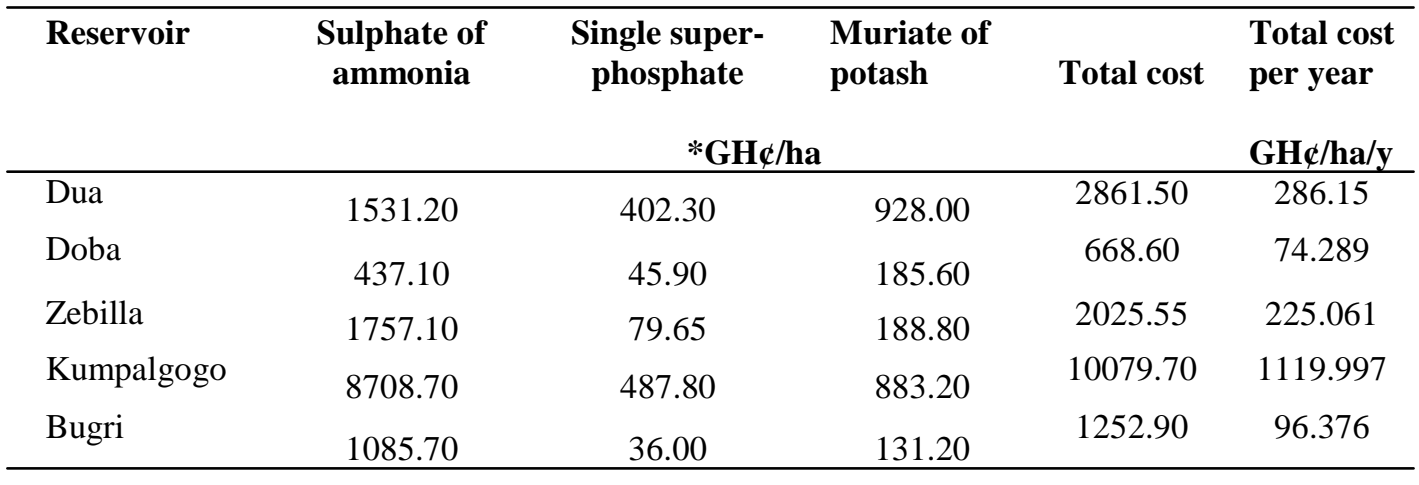

${ }^{*} G H \phi 1.42=U S D \$ 1$

uctivity should, recognize the following limitations (Enters, 1998):

a. Soil erosion does not only affect the nutrient status of the soil, but also its organic matter content and physical structure.

b. Soil nutrients may not be the most limiting factor in crop production.

c. Fertilizer applications are not necessarily the most cost effective options available to farmers for maintaining yields; in extreme cases, e.g. on deep and fertile soils, farmers may not even experience any yield decline with nutrient losses (Stocking, 1996).

d. It is only a proxy for actual productivity loss.

e. Mineral fertilizers supply nutrients in plant available forms, whereas erosion also removes fixed elements.

\section{CONCLUSION}

The study has amply shown that soil loss through erosion reduces top soil depth, nutrient stocks and the water holding capacity of catchment soils. This will adversely affect crop productivity, if no control measures are implemented. The total cost per year $\left(\mathrm{GH} \phi \mathrm{ha}^{-1} \mathrm{y}^{-1}\right)$ of fertilizers (sulphate of ammonia, single superphosphate and muriate of potash) needed to compensate for the lost nutrients ( $\mathrm{N}, \mathrm{P}$ and $\mathrm{K}$ ) in the catchment areas is more than what the resource poor farmer can afford. The cost incurred as a result of fertility erosion represents a hidden cost to agricultural production. Catchment area protection, is therefore needed to control erosion from the catchments and reduce both on-site (fertility and productivity loss) and off-site (sedimentation, pollution) impacts of erosion. These should include afforestation, improved cover using recommended cover and forage species, sustainable land management practices and vegetative barriers (vetiver) around reservoirs. Desilted nutrient-rich sediments could be used as a soil amendment to improve the productivity of catchment soils. This will require field experimentation to ascertain the benefits of these sediments in enhancing crop yields and biomass production. However, the heavy metals, pollutants/pathogens content of the desilted sediments must be ascertained through further research studies before they are used as soil amendments.

\section{ACKNOWLEDGEMENTS}

This study was made possible through financial and logistic support from the Federal Ministry of Education and Research, (BMBE) of Germany through the GLOWA-Volta Project of the Centre for Development Research (ZEF), University of Bonn, Bonn, Germany. 


\section{REFERENCES}

Acquaye, D. K. (1990). Towards Development of Sustainable Agriculture in Africa: Reflections of a Soil Scientists. In Zobisch, M. A. (ed). Proceedings of the $11^{\text {th }}$ Annual General Meeting of the Soil Society of Ghana, 19 28.

Adwubi, A., Amegashie, B. K., Agyare, W. A., Tamene, L., Odai, S. N., Quansah, C. and Vlek, P. (2009). Assessing sediment inputs to small reservoirs in Upper East Region, Ghana. Lakes \& Reservoirs: Research and Management, 14:279-287.

Asiamah, R. D. (1992). Soils and soil degradation of the Upper East Region of Ghana. Soil Research Institute, Kwadaso-Kumasi, Ghana.

Asiamah, R. D. and Antwi, B. O. (1988). Soil and water conservation in Ghana- past, present and future activities. Report sur les resources en sols du Monde, 63 FAO, Rome, pp 126-138.

Birner, R., Schiffer, E., Asante, F., Gyasi, O. and McCarthy, N. (2005). Analysis of Governance Structures for Water Resources Management in the White Volta Basin Ghana. Final Report. IFPRI, Washington DC, USA.

Black, C. A. (1965). Methods of soil analysis. Part 2. Chemical and microbiological properties. First edition. American Society of Agronomy and Soil Science Society of America. Madison, Wisconsin, USA.

Blake, G. R. and Harte, K. H. (1986). Bulk density. In: Klute, A. (ed.). Methods of soil analysis. Part 1. Physical and mineralogical methods. Second edition. American Society of Agronomy and Soil Science Society of America. Madison, Wisconsin USA. pp. 363 -375 .

Bøjö, J. (1996). The costs of land degradation in sub-Saharan Africa. Ecological Economics 16:161-173.
Bonsu, M. and Quansah, C. (1992). The importance of soil conservation for agricultural and economic development of Ghana. In Proceedings of the $12^{\text {th }}$ and $13^{\text {th }}$ Annual General Meetings of the Soil Science Society of Ghana, Accra, Ghana. pp. 77-80.

Bouyoucos, G. J. (1963). Hydrometer method improved for making particle size analyses of soils. Agronomy Journal 53:464 - 465.

Bremner, J. M. and Mulvaney, C. S. (1982). Total nitrogen. In: Page, A.L., Miller, R.H. and Keeney, D.R. (eds.). Methods of soil analysis. Part 2. Chemical and microbiological properties. American Society of Agronomy and Soil Science Society of America, Madison Wisconsin Inc. pp. 593 - 624.

Convery, F. and Tutu, K. (1990). Evaluating the Costs of Environmental Degradation: Ghana Applications of Economics in the Environmental Planning Process in Africa. University College of Dublin, Environmental Institute, Dublin.

Drechsel, P. and Gyiele, L. A. (1999). The economic assessment of soil nutrient depletion. Analytical issues for framework development. IBSRAM/SWNM. Issues in Sustainable Land Management 7, IBSRAM: Bangkok, 80p.

Ellison, W. D. (1950). Fertility Erosion. The Land, 9: 487.

Enters, T. (1998). A Framework for Economic Assessment of Soil Erosion and Soil Conservation. In: Penning de Vries, F.W.T., Agus, F. and Kerr, J. (Eds.) Soil Erosion at multiple scales. Principles and Methods for Assessing Causes and Impacts. CAB Publishing,

FAO, (1990). The conservation and rehabili- 
On-site effects and cost of fertility erosion. 92

tation of African lands. ARC/90/4. Rome: FAO

Folly, A. (1997). Land Use Planning to Minimize Soil Erosion - A Case Study from the Upper East Region in Ghana. Ph.D thesis, Institute of Geography, University of Copenhagen.

Gachene, C. K. K., Jarvis, N. J. and Mbuvi, J. P. (1997). Soil effects on soil properties in a highland area of Central Kenya. Soil Sci. Soc. Am. J., 61, 559-564.

GENSTAT (2007). GENSTAT Discovery Edition 3. VSN International, U.K.

GSS (2005). 2000 Population and housing census of Ghana. Ghana Statistical Service, Accra

Hudson, N. W. (1995). Soil Conservation. Third Edition, BT Batsford Ltd., London.

Kesse, G. O. (1985). The Mineral and Rock Resources of Ghana. Balkema, Rotterdam.

Lal, R. (1976). Soil Erosion Problems on an Alfisol in Western Nigeria and Their Control. IITA Monograph No. 1, 208 pp.

Lal, R. (1984). Soil Erosion From Tropical Arable Lands and Its Control. Advances in Agronomy, 37: 183 - 248.

Lal, R. (1987). Research Achievements towards Soil and Water Conservation in the Tropics: Potential and Prioritization. In: Pla Sentis, I. (ed.). Soil Conservation and Productivity. Maracay, Sociedal Venezolana de la Ciencia del Svelo: 755 - 87.

Liebe, J., Van de Giesen, N. and Andreini, M. (2005). Estimation of small reservoir storage capacities in a semi-arid environment: A case study in the Upper East Region of Ghana. Phys. Chem. Earth, 30: 448-54.
Mbagwu, J. S. C., Lal, R. and Scott, T. W. (1983). Physical Properties of Three Southern Nigeria. Soil Science, 136: 48- 55.

McLean, E. O. (1965). Aluminum. In: Black, C.A. (ed.). Methods of soil analysis. Part 2. Chemical and microbiological properties. First edition American Society of Agronomy and Soil Science Society of America, Madison, Wisconsin USA. pp. 978 - 998.

McLean, E. O. (1982). Soil pH and lime requirement. In: Page, A. L., Miller, R. H. and Keeney, D. R. (eds.). Methods of soil analysis. Part 2. Chemical and microbiological properties. Second edition. American Society of Agronomy and Soil Science Society of America, Madison, Wisconsin USA. pp.199223.

Ministry of Food and Agriculture (MoFA) (1998). National Soil Fertility Management Action Plan. Directorate of Crop Services, Accra, Ghana.

Ministry of Food and Agriculture (MoFA) (2008). Agriculture Sustainable Land Management Strategy and Action Plan (20092015). Ministry of Food and Agriculture, Accra, Ghana.

Ministry of Food and Agriculture (MoFA) (2009). Areas and Production of main rainfed crops in the Upper East Region of Ghana. MoFA, Bolgatanga, Ghana.

National Soil Erosion - Soil Productivity Research Planning Committee (NSE-SPRPC) (1981). Soil Erosion Effects on Soil Productivity. A Research Perspective. J. Soil, Water Conservation, 36(2): $82-90$.

Nelson, D. W. and Sommers, L. W. (1982). Total carbon, organic carbon and organic matter. In: Page, A.L., Miller, R.H. and Keeney, D.R. (eds.). Methods of soil analysis Part 2. Second edition. Chemical and microbiological properties. American Society of 
Agronomy and Soil Science Society of America. Madison, Wisconsin USA. pp.301-312.

Olsen, S. R. and Sommers, L. E. (1982). Phosphorus. In: Page, A.L., Miller, R.H. and Keeney, D.R. (eds.). Methods of soil analysis. Part 2. Chemical and microbiological properties. Second edition. American Society of Agronomy and Soil Science Society of America, Madison, Wisconsin USA. pp. 403 -430 .

Quansah, C. (1990). Soil erosion and Conservation in the Northern and Upper Regions of Ghana. Topics in Applied Resources Management, 2:135 - 157.

Quansah, C. (1997). Approaches to Replenishing Soil Fertility Depletion in Ghana. Poster Abstracts for the International Seminar on Approaches to Replenishing Soil Fertility in Africa: NGO Perspective, ICRAF, Nairobi, Kenya.

Quansah, C. and Baffoe-Bonnie, E. (1981). The effects of soil management systems on soil loss, runoff and fertility erosion in Ghana. In: Tingsanchali, T. and Egger, H. (eds). South-East Asia Regional Symposium on problems of soil erosion and sedimentation. Asia Institute of Technology, Bangkok, Thailand.

Quansah, C., Safo, E. Y., Ampontuah, E. O. and Amankwaah, A. S. (2000). Soil Fertility erosion and the associated cost of NPK removal under different soil and residue management in Ghana. Ghana Journal of Agriculture Science, 33(1): 33-42.

Rehm, S. (1978) cited in Lal, R. (1984). Soil
Erosion from Tropical Arable Lands and Its Control. Advances in Agronomy, 37: 183 248.

Sanchez, P. A., Buresh, A. J., Kwesiga, F. R., Mokwunge, A. U., Ndiritu, C. G., Shepherd, K. D., Soule, M. J. and Woomer, P. L. (1997). Soil Fertility Replenishment in Africa: An Investment in Natural Resource Capital. Proceedings of International Seminar on Fertility in Africa - NGO Perspectives ICRAF, Nairobi, Kenya.

Stocking, M. (1996). Soil erosion: Breaking new ground. In: Land degradation and societies (ed. Blaikie, P. and Brookfield, H.), pp. 49-63. London: Viliers Publication.

Swift, M. (1997). Biological Management of Soil Fertility: An Integrated Approach to Soil Nutrient Replenishment. Proceedings of International Seminar on Approaches to Replenishing Soil Fertility in Africa - NGO Perspectives. ICRAF, Nairobi, Kenya.

Thames, D. J. and Cassell, D. K. (1979). Land Farming Atlantic Coastal Plains Soils: Crop yield Relationships to Soil Physical and Chemical Properties. J. Soil Wat. Conserv. $30(1): 20-24$.

Warrick, A. W. (1998). Spatial Variability. In: Hillel, D. (Ed.) Environmental Soil Physics. Academic Press, USA. pp 655-675.

World Bank, Agence Française de Dévelopment and Royal Netherlands Embassy (2006). Ghana Country Environmental Analysis. AFTSD, Africa Region, Report № 36985-GH. 